\title{
ДЕЯКІ АСПЕКТИ ПЕРЕБІГУ ПАТОЛОГІЇ ГЕПАТОБІЛІАРНОЇ СИСТЕМИ В КОМОРБІДНОСТІ З ЕНДЕМІЧНИМ ЗОБОМ У ДІТЕЙ
}

\section{Тернопільський національний медичний університет імені І. Я. Горбачевського МОЗ України}

РЕЗЮМЕ. Ендемічний зоб є надзвичайно актуальною проблемою не лише для педіатрії, але й для сімейної медицини. Метою дослідження було узагальнити дані про клінічні особливості перебігу патології гепатобіліарної системи у дітей, хворих на ендемічний дифузний зоб (ЕДЗ), виявити закономірності перебігу хронічного холецистохолангіту у даного контингенту та сформувати рекомендації щодо корекції поєднаної патології. Для цього були використані такі матеріали та методи: обстежено 28 хворих на ЕД3, яким були проведені загальноклінічні обстеження гепатобіліарної зони та щитоподібної залози. В результаті проведених досліджень встановлено, що найпоширенішим супутнім захворюванням, що трапляється при ЕДЗ, $є$ хронічний холесцистохолангіт із латентним перебігом; з метою своєчасного виявлення і лікування цієї патології у таких пацієнтів слід акцентувати увагу на результатах додаткових методів дослідження; для профілактики гепатобіліарної патології потрібно детально контролювати режим та харчовий раціон підлітків, що проживають у ендемічних зонах, проводити медикаментозну профілактику йододефіциту.

КЛючОВІ СЛОВА: ендемічний зоб; хронічний холецистохолангіт; клінічна симптоматика; діти.

Вступ. Патологія печінки та жовчовивідних шляхів $\epsilon$ однією з найгостріших проблем сучасної гастроентерології, яка спостерігається у 10-15\% населення розвинутих країн [1, 2]. Незважаючи на очевидні успіхи, які досягнуті за останні десятиріччя в діагностиці та лікуванні цих захворювань, до сьогодні деякі питання остаточно не вирішені або $€$ суперечності з приводу їхнього тлумачення. Діти, що хворіють на ендемічний дифузний зо6, страждають на патологію печінки та жовчовивідних шляхів надзвичайно часто, близько 90 \% хворих [3]. В основі патогенезу зоба лежить розвиток йододефіциту в організмі, що $\epsilon$ наслідком не лише його недостатнього надходження із зовнішнього середовища, а й порушення розщеплення і засвоєння цього мікроелемента у шлунково-кишковому тракті, яке може бути спричинене змінами у гепатобіліарній системі [4].

Мета - узагальнити дані про клінічні особливості перебігу патології гепатобіліарної системи у дітей, хворих на ендемічний дифузний зоб (ЕДЗ), виявити закономірності перебігу хронічного хо- лецистохолангіту та сформувати рекомендації щодо корекції поєднаної патології.

Матеріал і методи дослідження. Обстежено 28 дітей, хворих на зоб, у комплекс діагностичного пошуку було включено загальноклінічні о6стеження гепатобіліарної зони та щитоподібної залози, ультразвукове досдідження (УЗД), визначення концентрації печінкових трансаміназ.

Результати й обговорення. Під наглядом перебували 28 дитини з ЕДЗ, із них $6(21,4 \%)$ - із зобом I ступеня, 20 (71,4 \%) - зі збільшенням щитоподібної залози II ступеня, 2 (7,2 \%) - із зобом III ступеня. Аналіз супутньої патології показав що 21 пацієнт $(75,0 \%)$ хворів на хронічний холецистохолангіт, 7 (25,5 \%) дітей мали патологію з боку лОР-органів, 8 (28,6 \%) - дефіцитну анемію. Детально розглянувши скарги і об'єктивні дані ми виявили, що у 17 (81 \%) пацієнтів з 21, що страждали на холецистохолангіт, перебіг даної патології був латентним. Ультразвукове обстеження печінки та жовчовивідних шляхів дало результати, які висвітлено у таблиці 1.

Таблиця 1. Результати ультразвукового дослідження гепатобіліарної системи у дітей, хворих на зоб

\begin{tabular}{|l|c|c|}
\hline \multicolumn{1}{|c|}{ Ознака } & \multicolumn{2}{c|}{ Кільксть хворих } \\
\cline { 2 - 3 } & $\mathrm{n}$ & \multicolumn{1}{c|}{} \\
\hline Ознаки холангіту в паренхімі печінки & 12 & 21,8 \\
\hline Деформація жовчного міхура & 6 & 17,8 \\
\hline Товщина стінки жовчного міхура більше 2 мм & 5 & 50,0 \\
\hline Товщина стінки жовчного міхура більше 3 мм & 14 & 10,7 \\
\hline Осад у жовчному міхурі & 3 & \\
\hline
\end{tabular}

Біохімічний аналіз крові з визначенням трансаміназ показав, що їх рівень майже у всіх дітей був у межах вікової норми, лише у двох пацієнтів аспартатамінотрансфераза була незначно підвищена. 
Огляди літератури, оригінальні дослідження, погляд на проблему, випадок з практики, короткі повідомлення

Функціональна активність щитоподібної залози у більшості 21 (75,0 \%) пацієнтів за результатами визначення активності гормонів щитоподібної залози була в межах норми. Гормонопродукуючу функцію ЩЗ вивчали шляхом фіксації вмісту в сироватці крові $\mathrm{T}_{3}$ та $\mathrm{T}_{4}$ за допомогою тест-систем фірми «Хема-медіка» за технологією та з компонентів фірми Diatech Diagnostics Inc., (США) методом імуноферментного аналізу.

Для лікування основного захворювання пацієнти з I та II ступенями ЕДЗ отримували йодовмісні препарати (йодид, струмозан, йодактив, біостар), 7 (25,0 \%) - левотироксин у терапевтичних дозах. При аналізі анамнезу виявлено прямий кореляційний зв'язок між тривалістю основного захворювання та змінами з боку гепатобіліарної системи.

\section{ЛІТЕРАТУРА}

1. Недельська С. М Захворювання гепатобіліарної системи та підшлункової залози у дітей : навчальний посібник для студентів 6 курсу медичного факультету, лікарів-інтернів, педіатрів, сімейних лікарів / С. М. Недельська, В. І. Мазур, Т. Є. Шумна. - Запоріжжя : ЗДМУ, 2017. -113 c.

2. Ультразвуковая и клинико-лабораторная диагностика истинных морфологических форм острого холецистита: необходимость смены классификации / И. М. Буриев, Г. Г. Мелконян, Н. С. Малюга [и др.] // Анналы хирургической гепатологии. - 2020. - № 25 (3). - С. 55-62.
Висновки. 1. Функціональна активність щитоподібної залози та медикаментозне лікування зоба певним чином впливають на стан гепатобіліарної системи;

2. Найпоширенішим супутнім захворюванням, що трапляється при зобі, є хронічний холесцистохолангіт із латентним перебігом;

3. 3 метою своєчасного виявлення і лікування патології печінки і жовчовивідних шляхів у дітей, хворих на зоб, при клінічному та лабораторному обстеженні слід більше уваги звертати на результати УЗД та біохімічного дослідження;

4. 3 метою профілактики гепатобіліарної патології у дітей, хворих на ЕДЗ, слід детально контролювати харчовий раціон та режим харчування підлітків, що проживають у ендемічних зонах, проводити медикаментозну профілактику йододефіциту.

3. Маменко М. $€$. Профілактика та лікування ендемічного зоба у дітей в регіонах із високою поширеністю поєднаного дефіциту йоду та заліза / М. Є. Маменко, О. І. Єрохіна, Н. М. Головченко // Український медичний альманах. - 2008. - Т. 11, № 5. - С. 101-104.

4. Стандарти надання медичної допомоги хворим із патологічними станами щитоподібної залози в умовах дії негативних чинників довкілля (видання друге, доповнене) / Під ред. О. В. Камінського. - К. : Старт-98, 2015. - 224 c.

\section{REFERENCES}

1. Nedelska, S.M., Mazur, V.I., \& Shumna, T.Ye. (2017). Zakhvoriuvannia hepatobiliarnoi systemy ta pidshlunkovoi zalozy u ditey: navchalnyi posibnyk dlia studentiv 6 kursu medychnoho fakultetu, likariv-interniv, pediatriv, simeinykh likariv [Diseases of the hepatobiliary system and pancreas in children textbook for 6th year students of medical faculty, interns, pediatricians, family doctors]. Zaporizhzhia: ZDMU [in Ukrainian].

2. Buriyev, I.M., Melkonyan, G.G., Malyuga, N.S., Pchelin, V.V., \& Shomakhov, M.G. (2020). Ultrazvukovaya i kliniko-laboratornaya diagnostika istinnykh morfologicheskikh form ostrogo kholetsistita: neobkhodimost smeny klassifikatsii [Ultrasound and clinical and laboratory diagnostics of true morphological forms of acute cholecystitis: the need to change the classification]. Annaly khirur- gicheskoy gepatologii - Annals of Surgical Hepatology, 25 (3), 55-62 [in Russian].

3. Mamenko, M.Ye., Yerokhina, O.I., \& Holovchenko, N.M. (2008). Profilaktyka ta likuvannia endemichnoho zoba u ditei v rehionakh iz vysokoiu poshyrenistiu poiednanoho defitsytu yodu ta zaliza [Prevention and treatment of endemic goiter in children in regions with high prevalence of combined iodine and iron deficiency]. Ukrainskyi medychnyi almanakh - Ukrainian Medical Almanac, 11, 5, 101-104 [in Ukrainian].

4. Kaminskyi, O.V. (Ed.) (2015). Standarty nadannia medychnoi dopomohy khvorym iz patolohichnymy stanamy shchytopodibnoi zalozy $v$ umovakh dii nehatyvnykh chynnykiv dovkillia (vydannia druhe, dopovnene). Kyiv: "Start 98» [in Ukrainian]. 
Огляди літератури, оригінальні дослідження, погляд на проблему, випадок з практики, короткі повідомлення

\section{НЕКОТОРЫЕ АСПЕКТЫ ТЕЧЕНИЯ ПАТОЛОГИИ ГЕПАТОБИЛИАРНОЙ СИСТЕМЫ В КОМОРБИДНОСТИ С ЭНДЕМИЧЕСКИМ ЗОБОМ У ДЕТЕЙ}

๑Л. Б. Романюк

Тернопольский национальный медицинский университет имени И. Я. Горбачевского МОз Украины

РЕЗЮМЕ. Эндемический зоб является чрезвычайно актуальной проблемой не только для педиатрии, но и для семейной медицины. Целью исследования было обобщить данные о клинических особенностях течения патологии гепатобилиарной системы у детей, больных эндемическим диффузным зобом (ЕДЗ), выявить закономерности течения хронического холецистохолангита у данного контингента и сформировать рекомендации по коррекции сочетанной патологии. Для этого были использованы следующие материалы и методы: обследовано 28 больных ЕДЗ, которым были проведены общеклинические обследования пищеварительной зоны и щитовидной железы. В результате проведенных исследований установлено, что наиболее распространенным сопутствующим заболеванием при ЕДЗ является хронический холесцистохолангит с латентным течением; с целью своевременного выявления и лечения данной патологии у таких пациентов следует акцентировать внимание на результатах дополнительных методов исследования; для профилактики пищеварительной патологии нужно тщательно контролировать режим и пищевой рацион подростков, проживающих в эндемичных зонах, проводить медикаментозную профилактику йододефицита.

КЛючЕВЫЕ СЛОВА: эндемический зоб; хронический холецистохолангит; клиническая симптоматика; дети.

\section{SOME ASPECTS OF THE PATHOLOGY OF THE HEPATOBILARY SYSTEM IN COMORBIDITY WITH ENDEMIC GOITER IN CHILDREN}

\section{Horbachevsky Ternopil National Medical University}

@L. B. Romanyuk

SUMMARY. Endemic goiter is an extremely important problem not only for pediatrics but also for family medicine. The aim of the study was to summarize the data on the clinical features of the pathology of the hepatobiliary system in children with endemic diffuse goiter (EDG), to identify patterns of chronic cholecystocholangitis in this contingent and to form recommendations for the correction of combined pathology. The following materials and methods were used for this purpose: 28 EDG patients were examined, who underwent general clinical examinations of the digestive zone and thyroid gland. As a result of the conducted researches it is established that the most widespread concomitant disease at EDG is a chronic cholecystocholangitis with a latent course; in order to timely identify and treat this pathology in such patients should focus on the results of additional research methods; for the prevention of digestive pathology, it is necessary to control in detail the regime and diet in adolescents living in endemic areas, to carry out of iodine deficiency medicine prevention.

KEY WORDS: endemic goiter; chronic cholecystocholangitis; clinical symptoms; children. 